\title{
A REVIEW ON CIPROFLOXACIN: DOSAGE FORM PERSPECTIVE
}

\author{
M. VIDYAVATHI*, G. SRIVIDYA \\ Institute of Pharmaceutical Technology, Sri Padmavati Mahila Visvavidyalayam, Tirupati 517502, A. P, India \\ Email: vidyasur@rediffmail.com \\ Received: 15 Feb 2018, Revised and Accepted: 24 May 2018
}

\begin{abstract} last decade.

Keywords: Ciprofloxacin, Drug delivery systems, Analytical methods DOI: http://dx.doi.org/10.22159/ijap.2018v10i4.25315

\section{INTRODUCTION}

Ciprofloxacin (CF) is an antibiotic which is available at a cheap cost [1] and used to treat many bacterial infections [2]. It belongs to fluoroquinolones category and is a broad spectrum second generation antibacterial agent [3]. It is mostly used to treat gram negative bacterial infections, urinary tract infections, skin, ophthalmic, respiratory, bone and joint, intraabdominal infections bacterial diarrheal infections [4] and periodontal pathogens [5]. But it is not effective against viral diseases. It is a nucleic acid synthesis inhibitor [6].
\end{abstract}

Ciprofloxacin (CF) is one of the topmost selling antibiotics and it is available at a cheap cost which is used to treat many bacterial infections. Many research scientists are working on this drug for various applications on different drug delivery systems. The main objective of this paper is to enlighten about the details of pure drug CF and its delivery systems along with current research on this drug. This review focused on history, pharmacokinetics, mechanism of action, types of dosage form available in the market with their cost, current research going on this drug with their applications and methods development for estimation of CF. It also highlighted the possible interactions and adverse drug reactions of CF and patents available. The present review revealed that the only analytical method for estimation of CF was developed in the first decade, few drug delivery systems (DDS) of CF were developed in the second decade and more research work on the development of novel DDS of CF founded in the

(C) 2018 The Authors. Published by Innovare Academic Sciences Pvt Ltd. This is an open access article under the CC BY license (http://creativecommons.org/licenses/by/4.0/)

It is one of the topmost selling antibiotics [1] and numbers of researchers are working with this drug for different applications or improvements in its applications.

Hence, the search criteria used in the present review were the research work on the development of novel drug delivery systems of $\mathrm{CF}$ in the last 3 decades (1985-2017) including the patents and different marketed products of CF with their price along with the properties and uses of CF. Properties [7] of CF are shown in table 1 and the storage temperatures required for different dosage forms is between $5-25^{\circ} \mathrm{C}[8]$.

Table 1: Properties of ciprofloxacin

\begin{tabular}{lll}
\hline Name of property & Description & Reference number \\
\hline State & Solid & 7 \\
Water solubility & $1.35 \mathrm{mg} / \mathrm{ml}$ & \\
Melting point $\left({ }^{\circ} \mathrm{C}\right)$ & $255-257$ & \\
Log P & -0.57 & \\
pKa (Strongly Acidic) & 5.76 \\
pKa (Strongest Basic) & 8.68 & \\
Biological half-life & $3.5 \mathrm{~h}$ & \\
\hline
\end{tabular}

\section{History}

Quinolones were first developed in 1960's, then they were classified into generations based on antimicrobial activity. In the first generation, nalidixic acid was developed in 1962 to treat urinary tract infections and later in 1980 by insertion of $\mathrm{F}$ atom in quinolone ring a 2nd generation CF was developed to treat a number of infections [9].

\section{Pharmacokinetic parameters}

The pharmacokinetic parameters of CF are listed in table 2

\section{Absorption}

$60-80 \%$ CF is rapidly absorbed with $t_{\max }$ of 1 to $1.5 \mathrm{~h}$, when given by oral route and it has no significant effect when administered with food, but altered with ingestion of sucralfate, $\mathrm{Fe}_{2} \mathrm{SO}_{4}$ and antacids [7].

\section{Distribution}

It penetrates well into the most of the body fluids and tissues. Tissue concentrations often exceed serum concentrations in both men and women, particularly in genital tissue, including the prostate [3].

\section{Metabolism}

It is metabolized into oxoCF, sulfoCF and other active metabolites. On oral administration, approximately $15 \%$ of the dose is converted into four metabolites identified in human urine which are less active than unchanged CF [8].

\section{Elimination}

$50 \%$ of CF are eliminated by kidney, $15 \%$ by feces, and $45 \%$ of liver and other intestinal mucosal secretions [3].

\section{USES/Indication}

CF is used to treat acute sinusitis, lower respiratory tract infection, chronic bronchitis, hospital acquired pneumonia, kidney, urinary tract, diarrheal and abdominal infections, skin and soft tissue, bone and joint infections, acute otitis and uncomplicated cystitis and gonorrhea.

\section{Mechanism of action}

The fluoroquinolones act by inhibiting type 2 bacterial DNA topoisomerases, DNA gyrase and topoisomerase IV. They bind and 
trap the enzyme-DNA complex [6]. This blocks DNA synthesis and cell growth and ultimately shows a lethal effect on the cell [7].
Different mechanisms of actions of CF against different organisms are shown in table 3.

Table 2: Pharmacokinetic parameters

\begin{tabular}{lll}
\hline Parameter & Values & Reference number \\
\hline Half life & 3 to $4 \mathrm{~h}$ & $3,7,8$ \\
Bioavailability (Oral) & $69 \%$ & \\
Renal excretion & $70 \%$ & \\
Plasma protein binding & $30 \%$ & \\
Volume of distribution & $2 / 3.5 \mathrm{~L} / \mathrm{kg}$ \\
Hepatic metabolism & $5 \%$ & \\
\hline
\end{tabular}

Table 3: List of target enzymes of different organisms inhibited by ciprofloxacin

\begin{tabular}{lll}
\hline Target enzyme & Organism & Reference number \\
\hline DNA topoisomerase 4 subunit 4 A & Haemophilus influenza, Staphylococcus aureus & 6,7 \\
$\begin{array}{l}\text { DNA topoisomerase 2-alpha and K+-voltage-gated } \\
\text { channel subfamily H member }\end{array}$ & Human & \\
DNA gyrase subunit A & Haemophilus influenzae, Escherichia coli (strain K12), Bacillus \\
& $\begin{array}{l}\text { subtilis (strain 168), Staphylococcus aureus } \\
\text { Bacillus subtilis (strain 168) }\end{array}$ \\
DNA topoisomerase 4 subunit 4 B & Escherichia coli & \\
Multidrug resistant protein MdtK &
\end{tabular}

\section{Dosage forms}

$\mathrm{CF}$ is available in the market as tablet, infusion, eye drops, suspensions, ointments with varying cost prepared by a number of companies to treat various bacterial infections. Table 4 illustrated the number of dosage forms of $\mathrm{CF}$ available with their cost range and number of companies manufacturing these $\mathrm{CF}$ dosage forms [10].

Table 4: Different dosage forms of ciprofloxacin available in the market with cost

\begin{tabular}{llll}
\hline Dosage form & Available number & Cost range (Rs) & Number of manufacturing companies \\
\hline Tablets & 214 & $8-125 / 10$ tablets & 98 \\
Infusion & 17 & $17.86-/ 100 \mathrm{ml}$ & 14 \\
Eye drops & 28 & $6-24.80 / 10 \mathrm{ml}$ & 24 \\
Suspensions & 4 & $27.76-48.50 / 60 \mathrm{ml}$ & 4 \\
Ointments & 4 & $4.31-10 / 5 \mathrm{ml}$ & 4 \\
\hline
\end{tabular}

Table 5: Different drug delivery systems of ciprofloxacin developed

\begin{tabular}{|c|c|c|c|}
\hline Type of drug delivery system & Name of formulation & Application & $\begin{array}{l}\text { Reference } \\
\text { number }\end{array}$ \\
\hline Gastro retentive floating DDS & Tablets & To achieve the controlled release of the drug & 13 \\
\hline Ophthalmic DDS & In-situ gel & To achieve sustained drug release & 14 \\
\hline Cutaneous wound closures & Hydrogels & To treat the wounds infected by pseudomonas aeruginosa. & 15 \\
\hline Controlled release DDS & Films & To treat periodontitis & 16 \\
\hline $\begin{array}{l}\text { Gastro retentive sustained } \\
\text { release DDS }\end{array}$ & Microbeads & To Prolong duration of action & 17 \\
\hline Targeted DDS & Elastic liposomes & To treat acne vulgaris & 18 \\
\hline Sustained release DDS & Floating matrix tablets & To extend absorption of CF. & 19 \\
\hline Sustained release DDS & Tablets & To prolong the drug release & 20 \\
\hline Controlled DDS & Dental films & To treat periodontitis & 5 \\
\hline Ophthalmic DDS & Ocular Inserts & To treat ocular conjunctivitis & 21 \\
\hline Wound closures & Composite films & For wound healing & 22 \\
\hline Floating bioadhesive DDS & Tablets & $\begin{array}{l}\text { To increase the stay period of drug in its absorption area and } \\
\text { to decrease the dosing interval }\end{array}$ & 23 \\
\hline Swellable and gastro-retentive DDS & Tablets & To prolong gastric emptying time & 24 \\
\hline Topical DDS & Films & To treat periodontitis & 25 \\
\hline Ophthalmic DDS & Insitu gel & $\begin{array}{l}\text { To treat eye infections like dacrocystitis, bacterial } \\
\text { conjunctivitis corneal ulceration }\end{array}$ & 26 \\
\hline Multi-unit floating DDS & Beads & To know about the effect of additives & 27 \\
\hline Extended-release DDS & Tablets & To Prolong duration of the release & 28 \\
\hline $\begin{array}{l}\text { The novel vesicular carrier } \\
\text { system }\end{array}$ & Niosomal cream & To improve skin retention and prolong the local effect on skin & 29 \\
\hline
\end{tabular}

\section{Patents filed/Sanctioned}

As per FDA, 12 patents are found in literature for different products or activities and also a list of 20 patents are given in the drug bank [11,12].

\section{Current research on ciprofloxacin}

\section{Development of drug delivery systems (DDS)}

As CF is a broad spectrum antibiotic it acts on a wide range of organisms and prescribed by many doctors, the present review work on $\mathrm{CF}$ is undertaken. The research work was conducted on this drug to improve its applications in different diseased conditions by many scientists. Most of the research work was carried out to formulate liposomes, films, niosomal creams, gastro-retentive tablets, hydrogels, dental films, ocular inserts, and microbeads. It is also used to treat acne vulgaris which is a common chronic disease of the sebaceous follicles in the form of the liposome drug delivery system. The gastro-retentive tablets were formulated to improve absorption of the drug as it has a narrow absorption window. Likewise, it is used to treat periodontitis, which is effective against 
periodontal pathogens, in the form of dental films. Ocular inserts were developed to treat ophthalmic infections. Hence, the list of research work conducted on CF by many researchers is shown in table 5 .

\section{Analytical methods for estimation of ciprofloxacin}

Several analytical methods for the quantitative determination of $\mathrm{CF}$ in pharmaceutical formulations were developed like electrophoresis, UV spectrophotometry, titration, and HighPerformance Liquid Chromatography (HPLC). Quantification is necessary to determine the quality of medicine, which are available in the market.

Which are later used for quantification of $\mathrm{CF}$ in urine, plasma, animal tissue, and other samples. Methods developed for estimation of CF in different samples are given in table 6 .

Table 6: Analytical methods for estimation of Ciprofloxacin in different samples

\begin{tabular}{|c|c|c|c|}
\hline Sample & Method & Application & $\begin{array}{l}\text { Reference } \\
\text { number }\end{array}$ \\
\hline Body fluids & HPLC & This method is ideal for clinical trials and PK studies of CF & 30 \\
\hline Biological fluids & HPLC & To study the pharmacokinetics of CF & 31 \\
\hline Plasma and urine & HPLC & $\begin{array}{l}\text { Used to measure only the parent drug in human serum and urine } \\
\text { but not metabolites }\end{array}$ & 32 \\
\hline $\begin{array}{l}\text { Pharmaceutical preparations } \\
\text { and biological fluids }\end{array}$ & RP-HPLC & $\begin{array}{l}\text { Separation of compounds and to determine the pharmacokinetics } \\
\text { of } \mathrm{CF}\end{array}$ & 33 \\
\hline Pharmaceutical preparations & HPLC & Quantitative determination of $2^{\text {nd }}$ generation quinolones & 34 \\
\hline Ophthalmic solution & $\begin{array}{l}\text { UV-Visible } \\
\text { spectrophotometry }\end{array}$ & $\begin{array}{l}\text { The first derivative method is successfully applied (difficulty with } \\
\text { excipients can overcome by selecting at appropriate wavelength) }\end{array}$ & 35 \\
\hline Pharmaceutical preparations & HPLC with UV detection & Highly efficient for quantification in matrices evaluated & 9 \\
\hline Serum and urine & HPLC & $\begin{array}{l}\text { To study the pharmacokinetics of CF in patients receiving } \\
\text { multiple drug therapy }\end{array}$ & 36 \\
\hline
\end{tabular}

\section{Interaction and reactions with ciprofloxacin}

Two types of possible interactions were found, those are drug-drug and drug-food interaction as shown below

\section{Drug-drug interaction}

As CF is an inhibitor of CYP $1 \mathrm{~A} 2$, the drugs majorly metabolized by CYP 1A2 metabolized drugs have shown increased plasma concentrations when co-administered with CF [37]. Hence, CYP1A2 metabolized drugs shown adverse reactions when administered along with CF [38]. They are around 275 drug interactions listed in drug bank [7]. But some drug interactions with CF based on drugs category and its effects are shown in table 7.

\section{Drug-food interaction}

$\mathrm{CF}$, when taken with food, decreased the rate, but not the extent of absorption of CF [39]. List of food interactions with $\mathrm{CF}$ and its effects are shown in table 8.

Table 7: List of drug interactions of ciprofloxacin and its effects

\begin{tabular}{ll}
\hline Category & Effect \\
\hline Caffeine and xanthine derivative & Reduced clearance of caffeine and a prolongation of its serum half-life \\
Class IA or III Antiarrhythmics & CF may have an additive effect on the QT interval \\
Histamine H2-receptor Antagonists & No significant effect on the bioavailability of CF. \\
Multivalent Cations & Lower serum and urine levels \\
Nonsteroidal Anti-Inflammatory Drugs & Increase the risk of central nervous system stimulation and convulsive \\
(NSAIDs) & seizures. \\
Oral Anticoagulants & Increase in oral anticoagulant activity \\
\hline
\end{tabular}

Table 8: List of interactions with ciprofloxacin dosage forms and its effects

\begin{tabular}{llll}
\hline Dosage form & With & Effect & Reference number \\
\hline Tablet & Food & Delay in the absorption of CF & 39 \\
Suspension & Food & No delay is observed & 39 \\
Any formulation & Dairy products/Calcium-fortified juices & Decrease in the absorption of CF & \\
\hline
\end{tabular}

Table 9: Adverse drug reactions of ciprofloxacin

\begin{tabular}{|c|c|c|}
\hline Organ/System name & ADR & $\begin{array}{l}\text { Reference } \\
\text { number }\end{array}$ \\
\hline CNS & $\begin{array}{l}\text { Nervousness, agitation, insomnia, anxiety, nightmares, dizziness, confusion, tremors, hallucinations, } \\
\text { psychotic reaction, depression }\end{array}$ & $38,39,40$ \\
\hline CVS & Orthostatic hypotension, Vasculitis & \\
\hline EYE & $\begin{array}{l}\text { Blurred vision, burning, stinging, irritation, } \\
\text { itching, tearing, and redness of eyes, eyelid itching, swelling, or crusting, sensitivity to light }\end{array}$ & \\
\hline GI System & $\begin{array}{l}\text { Nausea, vomiting, diarrhea, constipation, abdominal pain or discomfort, dyspepsia, dysphagia, } \\
\text { flatulence, pancreatitis, pseudomembranous colitis }\end{array}$ & \\
\hline Urinary system & Albuminuria, candiduria, renal calculi & \\
\hline Skin & $\begin{array}{l}\text { Rashes, exfoliative dermatitis, toxic epidermal necrolysis, erythema, Toxic epidermal necrolysis, } \\
\text { Stevens-Johnson syndrome }\end{array}$ & \\
\hline Hepatic system & Jaundice, hepatic necrosis & \\
\hline Musculoskeletal system & Myalgia, myoclonus, tendinitis, tendon rupture & \\
\hline Others & Phototoxicity & \\
\hline
\end{tabular}




\section{Adverse drug reactions (ADRs) of CF}

$\mathrm{CF}$ use is associated with disabling and potentially irreversible serious adverse reactions [38, 39]. CF has also shown some adverse effects on different organs or systems of the body as shown below in table 9 [40].

\section{Miscellaneous research works on ciprofloxacin}

Some different results were found during research on $\mathrm{CF}$ and its dosage forms by a number of scientists and are discussed below.

Janis Vella et al., conducted studies on "factors affecting the penetration of CF in lower extremity ischemic tissues" indicated the decreased tissue concentrations of $\mathrm{CF}$ in patients suffering from more severe forms of the peripheral arterial disease (PAD) [41].

V. V. Sarveshwer Rao et al., conducted studies on "Circadian variation in urinary excretion of $\mathrm{CF}$ after a single-dose oral administration at 1000 and $2200 \mathrm{H}$ in Human subjects" and found a significant decrease in the rate and extent of $\mathrm{CF}$ excretion during their study [42]. Tomasz Kloskowski et al., proposed that this drug can serve as an adjuvant treatment for lung cancer, due to its capacity of topoisomerase II inhibition [43].

Imran Hayder et al., indicated that $\mathrm{TiO}_{2}$-based photocatalysis is a feasible way to inactivate the $\mathrm{CF}$ drug, as a pretreatment prior to further biological treatments [44]. Gayatri Devi Singh et al., indicated that, with an increase in duration of UV and sunlight treatment duration, the rate of degradation was increased, and led to the gradual inactivation of the antibiotic [45]. Abbas Khan et al., indicated the change of pharmacokinetics of CF when coadministered with diclofenac eye drops [46]. Ron E. Polk et al., resulted in the possibility of renal failure associated with the concomitant administration of cyclosporine and CF [47].

A study on "Comparative Activity of CF, Levofloxacin and Moxifloxacin against Klebsiella pneumoniae, Pseudomonas aeruginosa and Stenotrophomona maltophilia assessed by minimum inhibitory concentrations and time-kill Studies indicated the activity of CF and levofloxacin antibiotics are equivalent [48].

Danni ramdhani et. al conducted studies on "Ciprofloxacin resistance among clinical isolates from acute respiratory infections patients at community health centers in tasikmalaya, indonesia" indicated that level of antibiotic (CF) resistance was mediated resistance [49].

\section{CONCLUSION}

The present review revealed that analytical methods to determine CF was developed for its pharmacokinetic studies in the first decade of the selected review period (1985-1995). In the second decade, the research work on the development of drug delivery systems of CF was found in the literature. Whereas more research papers were found in the development of novel drug delivery systems of CF in third decade compared to the last 2 decades. The review on CF will be useful for further applications and development of improved drug delivery systems as it helps in the understanding of available applications, drug delivery systems with the already found results/reports on increased bioavailability, prolonged release, gastric retention etc.

\section{AUTHORS CONTRIBUTIONS}

All the author have contributed equally

\section{CONFLICT OF INTERESTS}

\section{Declared none}

\section{REFERENCES}

1. https://books.google.co.in/books. [Last accessed on 10 Jan 2018]

2. https://www.medicinenet.com/ciprofloxacin/article.htm. [Last accessed on 10 Jan 2018]

3. Mark FL, James ML, Lanc J, Robert HW, Edward EC, Margerison, et al. Ciprofloxacin and the fluoroquinolones. Am J Med 1989;87:2-8.
4. Pichler H, Diridl G, Wolf D. Ciprofloxacin in the treatment of acute bacterial diarrhea: a double-blind study. Eur J Clin Microbiol 1986;5:241-3.

5. Umadevi S, Rohini B, Nithyapriya, Sasidharan. Formulation and evaluation of ciprofloxacin dental films for periodontitis. J Chem Pharm Res 2012;4:2964-71.

6. Committee on Antimicrobial Agents, Canadian Infectious Disease Society, Thomas JL. Ciprofloxacin: an oral quinolone for the treatment of infections with gram-negative pathogens. Can Med Assoc J 1994;150:669-76.

7. Wishart DS, Knox C, Guo AC, Shrivastava S, Hassanali M, Stothard P, et al. Drugbank: a comprehensive resource for in silico drug discovery and exploration. Nucleic Acids Res 2006;34:668-72.

8. http://www.drugsupdate.com/generic/view/475/ciprofloxaci n. [Last accessed on 10 Jan 2018]

9. Scherer R, Jessica P, Juliete F, Mariana L, Mayara L. Determination of ciprofloxacin in pharmaceutical formulations using HPLC method with UV detection. Indian J Pharm Sci 2014;76:541-4

10. http://www.medindia.net/drug-price/CIPROFLOXACIN.htm. [Last accessed on 10 Jan 2018]

11. https://www.fda.gov/downloads/Drugs/ResourcesForYou/Co nsumers/BuyingUsingMedicineSafely/GenericDrugs/UCM564 441.pdf. [Last accessed on 10 Jan 2018]

12. https://pubchem.ncbi.nlm.nih.gov/compound/ciprofloxacin. [Last accessed on 10 Jan 2018]

13. Madan MG, Maulesh MC, Madhulika G. Formulation development and evaluation of gastro retentive floating tablet of ciprofloxacin hydrochloride. Int J Pharm Pharm Sci 2016;8:149-52.

14. SB Makwana, VA Patel, SJ Parmar. Development and characterization of in-situ gel for the ophthalmic formulation containing ciprofloxacin hydrochloride. Results Pharma Sci 2016;6:1-6.

15. Daniel CR, Seth T, David MB, Nicole LW, Sandra CB, Luke RB, et al. Ciprofloxacin-loaded keratin hydrogels prevent pseudomonas aeruginosa infection and support healing in a porcine full-thickness excisional wound. Adv Wound Care 2014;4:457-68.

16. Ashwin K, Ramesh S, Ramesh, Sudhakar B, Goverdhan Reddy P. Design and evaluation of biodegradable periodontal films containing ciprofloxacin and ornidazole. Sch Acad J Pharm 2013;2:60-9.

17. Smriti M, Jitendra P, Sumeet D. Formulation and evaluation of floating microbeads of ciprofloxacin hcl by emulsion gelation method. Int J Pharm Life Sci 2013;4:2876-84.

18. Raheem SA, Hussein AH, Abbashayder K, Matrood MK, Azeez OS. Effect of method of preparation on physical properties of ciprofloxacin hcl elastic liposomes intended to be utilized in the treatment of acne vulgaris. Int J Res Ayur Pharm 2013;4:742-6.

19. Sathish Reddy E, Mohammed MI, Syed MK, Syed AB, Mohammed I. Formulation and evaluation of sustained release floating tablets of ciprofloxacin with hepato-protectant. Int J Pharm Appl 2012;3:289-92.

20. Mudgul VK, Rajat K, Saraogi GK, Singhai AK, Sharma D. Formulation and evaluation of sustained release floating tablets of ciprofloxacin. Int Res J Pharm 2012;3:120-2.

21. Mohamed AA, Mohamed AA, Mohamed SH. Design and evaluation of ciprofloxacin hydrochloride ocular inserts. Int J PharmTech Res 2011;3:1750-63.

22. Himabindu TVL, Vidyavathi M, Kavitha, Sastry TP, Suresh Kumar RV. Preparation and evaluation of ciprofloxacin loaded chitosan-gelatin composite film for wound healing activity. Int J Drug Delivery 2010;2:173-82.

23. Mukhopadhyay S, Goswami L, Satheesh MNV, Upadhyaya K. Formulation and evaluation of floating bioadhesive tablets of ciprofloxacin hydrochloride by direct compression technique. Int J Pharm Pharm Sci 2010;2:113-5.

24. Ramji AKA, Chandra Sekhara Rao G, Prabhakar Reddy V. Formulation and evaluation of swellable and floating gastroretentive ciprofloxacin hydrochloride tablets. AAPS Pharm Sci Tech 2009;10:220-6. 
25. Mohammed GA, Harish NM, Narayana Charyulu R, Prabhakar P. Formulation of chitosan-based ciprofloxacin and diclofenac film for periodontitis therapy. Trop J Pharma Res 2009;8:33-41.

26. Chandra Mohan E, Jagan Mohan K, Venkatesham A. Preparation and evaluation of in-situ-gels for ocular drug delivery. J Pharm Res 2009;2:1089-94.

27. Srinatha A, Jayanta KP. Multi-unit floating alginate system: effect of additives on ciprofloxacin release. Drug Delivery 2008; 15:471-6.

28. Varshosaz J, Tavakoli N, Roozbahani F. Formulation and in vitro characterization of ciprofloxacin floating and bioadhesive extended-release tablets. Drug Delivery 2006;13:277-85.

29. Rockade VS, Kadu PK. Formulation and evaluation of novel anti bacterial ciprofloxacin loaded niosomal cream. Int Res J Pharm 2015;6:519-27.

30. Weber A, Chaffin D, Smith A, Opheim KE. Quantitation of ciprofloxacin in body fluids by high-pressure liquid chromatography antimicrobial agents and chemotherapy. J Pharma Biomed Anal 1985;27:531-5.

31. Jehl F, Gallion C, Debs J, Brogard JM, Monteil H, Minck R. Highperformance liquid chromatographic method for determination of ciprofloxacin in biological fluids. J Chromatography 1985;339:347-57.

32. Marika K, Kimiko T, Tsutomu K, Koichi N, Shigeyuki N. Determination of ciprofloxacin in plasma and urine by HPLC with ultraviolet detection. Clin Chem 1998;44:1251-5.

33. Zotou A, Miltiadou N. Sensitive LC determination of ciprofloxacin in pharmaceutical preparations and biological fluids with fluorescence detection. J Pham Biomed Anal 2002;28:559-68.

34. Najla MK, Anil Kumar S, Erika Rosa MKH, Maria IR, Miritello S. Quantitative determination of ciprofloxacin and norfloxacin in pharmaceutical preparations by High performance liquid chromatography. Rev Bras Cienc Farm Brazilian J Pharm Sci 2005;41:507-13.

35. Edith CLC, Rudy B, Magali BA, Hérida RN. A first-derivative spectrophotometric method for the determination of ciprofloxacin hydrochloride in ophthalmic solution. Physical Chem 2012;2:116-22.

36. Nix DE, De Vito JM, Schentag JJ. Liquid-chromatographic determination of ciprofloxacin in serum and urine. Clin Chem 1985;31:684-6.

37. Marika T Granfors, Janne TB, Mikko N, Pertti JN. Ciprofloxacin greatly increases concentrations and cypotensive effect of tizanidine by inhibiting its cytochrome P450 1A2-mediated presystemic metabolism. Clin Pharmacol Ther 2004;76:598606.

38. FDA package insert ciprofloxacin $\mathrm{HCl}$, Bayer HealthCare Pharmaceuticals Inc. Initial U. S. Approval; 1987.

39. CIPRO $($ CIPROFLOXACINhydrochloride)TABLETSCIPRO $®(C I$ PROFLOXACIN*)ORAL SUSPENSION; FDA leaf let. Available from:

https://aidsinfo.nih.gov/drugs/458/ciprofloxacin/69/professi onal. [Last accessed on 10 Jan 2018]

40. Janis V, Maria V, Kevin C, Liberato C, Anthony SI, Lilian MA, et al. Factors affecting penetration of CIPROFLOXACIN in lower extremity ischemic tissues. Int $\mathrm{J}$ Low Extrem Wounds 2016;15:126-31.

41. Sarveshwer Rao VV, Rambhau D, Ramesh Rao B, Srinivasu P. Antimicrobial agents and chemotherapy circadian variation in urinary excretion of ciprofloxacin after a Single-Dose Oral Administration at 1000 and $2200 \mathrm{H}$ in human subjects. Antimicro Agents Chemother 1997;41:1802-4.

42. Tomasz K, Natalia G, Joanna O, Jakub MN, Jan A, Jakub T, et al. Ciprofloxacin is a potential topoisomerase ii inhibitor for the treatment of NSCLC. Int J Oncol 2012;41:1943-9.

43. Imran $\mathrm{H}$, Ishtiaq AQ, Ali Awan M, Muhammad AK, Aftab $\mathrm{T}$. Degradation and inactivation of ciprofloxacin by photocatalysis using $\mathrm{Tio}_{2}$ nanoparticles. J Appl Pharm 2012;1:487-97.

44. Gayatri DS, Gupta KC. Photo and UV degradation of ciprofloxacin Antibiotic. Int J Curr Microbiol Appl Sci 2014;3:641-8.

45. Abbas K, Zafar I, Muhammad IK, Jamshaid AK, Muhammad KJ, Zia A. Drug-drug interaction between ciprofloxacin and diclofenac ophthalmic drops at ocular level. Afr J Pharm Pharmacol 2011;5:2566-74.

46. Ron EP. Drug-drug interactions with ciprofloxacin and other fluoroquinolone. Am J Med 1989;87:76-81.

47. Antoine G, Frédéric S, Magali K, François J. Comparative activity of ciprofloxacin, levofloxacin and moxifloxacin against Klebsiella pneumoniae, Pseudomonas Aeruginosa and Stenotrophomonas Maltophilia assessed by minimum inhibitory concentrations and time-kill studies. J Pone 2016;11:1-10.

48. Danni R, Sri agung FK, Resmi M, Elin F, Dede S, Mokhamad A. Ciprofloxacin resistance among clinical isolates from acute respiratory infections patients at community health centers in tasikmalaya, Indonesia. Asian J Pharm Clin Res 2017;Special Issur: 43-5. 